\title{
A COMPARISON OF THE QUINHYDRONE AND HYDRO- GEN ELECTRODES IN SOLUTIONS CONTAINING TANNIN
}

\author{
E. L. Wallace and John Beek, jr.
}

\section{ABSTRACT}

Measurements of $\mathrm{pH}$ are made with the hydrogen and quinhydrone electrodes in solutions of tanning extracts and in systems consisting of leather and water in equilibrium. Comparison of the values obtained with the two electrodes indicates that the quinhydrone electrode can not be substituted for the hydrogen electrode in solutions of the types studied. However, a satisfactory correction could be applied for the leathers studied, a necessary condition being that the nature of the solution be exactly known. In the case of tanning extracts, the errors involved were too great to be disregarded.

\section{CONTENTS}

I. Introduction- Page

II. Purpose

III. Apparatus and materials

IV. Experimental method

V. Discussion of results

\section{INTRODUCTION}

In laboratories which handle a large quantity of analytical or control work in connection with the leather industry, a method for $\mathrm{pH}$ determination which is rapid and simple is highly desirable. The quinhydrone electrode developed by E. Biilmann ${ }^{1}$ provides such a method; and, when its use became general, there was a tendency in leather laboratories to accept the results obtained with this electrode as equivalent to hydrogen electrode values.

Several investigators ${ }^{2}$ have noted discrepancies between measurements made with the quinhydrone and the hydrogen electrode. Quite recently, Pleass ${ }^{3}$ has reported on An Investigation of the Methods Employed for the Determination of the $\mathrm{pH}$ Value of Tan Liquors and Lime Liquors.

Pleass found that a colorometric method gives fairly good results if used with proper precautions; that the glass electrode gives correct results for all conditions investigated; that the results obtained with the hydrogen electrode are correct if the density of the liquor is less than $60^{\circ} \mathrm{Bk}$. and the liquor is free from substances leading to an oxidation-reduction potential, such as sulphites and sulphides; that

1 Ann. Chim., 15, p. 109; and 16, p. 321; 1921.

2 Atkin and Thompson, J. S. L. T. C., 8, p. 183; 1924 . De La Bruere, J. S. L. T. O., 9, p. 438; $1925 . \quad$ J.

A. Wilson, The Chemistry of Leather Manufacture, 2d ed., 1, p. 108.

3 J. Soc. Chem. Ind., 48, p. 152 T; 1929. 
"the quinhydrone electrode was unreliable for all the trade tan liquors examined."

In view of the general use of the quinhydrone electrode, it seemed worth while to investigate the possibility of finding a correction factor to be used in interpreting results to be obtained with this method. It is to be noted that Pleass's examination was confined to "trade tan liquors," which were presumably indefinite blends of different kinds of tanning materials. In our work, each type of material has been investigated separately, in solutions of known composition, with the thought that if a correction factor for each type could be found, it might be possible to explain the discrepancies noted when blended liquors are examined.

\section{PURPOSE}

In connection with other work under way at this bureau it is necessary to make hundreds of measurements of the $\mathrm{pH}$ values of leather. For this purpose it was desired to use the quinhydrone electrode because of its greater speed. A comparison has, therefore, been made of the quinhydrone and the hydrogen electrodes when used to measure the $\mathrm{pH}$ values of leather as well as the $\mathrm{pH}$ values of tanning liquors.

\section{APPARATUS AND MATERIALS}

The apparatus used in this work was designed for the rapid handling of a large number of routine samples rather than for accurate measurement. (Fig. 1.) However, the accuracy of the apparatus is better than the reproducibility of electrometric measurements in the solutions in question. Six solution bridges $(A)$ furnished with stopcocks are arranged radially about a central well $(B)$ of saturated $\mathrm{KCl}$ solution, which in turn is connected through a bridge $(C)$ of the same solution and another well $(D)$ to the reference half-cell $(E)$. The reference half-cell is a saturated $\mathrm{KCl}$ calomel electrode. A saturated $\mathrm{KCl}$ solution was used for electrical contact with the solutions investigated, ${ }^{4}$ in order to eliminate as nearly as possible any error due to contact potential. Dropping funnels $(F)$ are inserted in the top of the central well and in the electrode cell so that the system may be flushed out to prevent contamination. In the case of the solutions of tanning extract a bridge consisting of an agar gel saturated with $\mathrm{KCl}$ was inserted between the extract and $\mathrm{KCl}$ solutions.

The hydrogen electrodes $(G)$ used were of the Hildebrand type, the electrodes being of platinum, plated with electrolytically deposited palladium black. The hydrogen was supplied direct through a manifold from a tank $(H)$ of the commercial product.

Gold wires about $0.6 \mathrm{~mm}$ in diameter, sealed in glass tubes with about $1 \mathrm{~cm}$ projecting, were used for the quinhydrone electrodes. The quinhydrone was prepared in this laboratory by the method of Biilmann and Lund. ${ }^{5}$

The apparatus was checked frequently with $N / 20$ potassium acid phthalate solution, and was always found to be correct within the experimental error of the work.

4 Loomis, N. E., and Acree, S. F., 4m. Chem. J., 46, p. 621; 1911

3 Ann. Chim., 16, p. 321. 


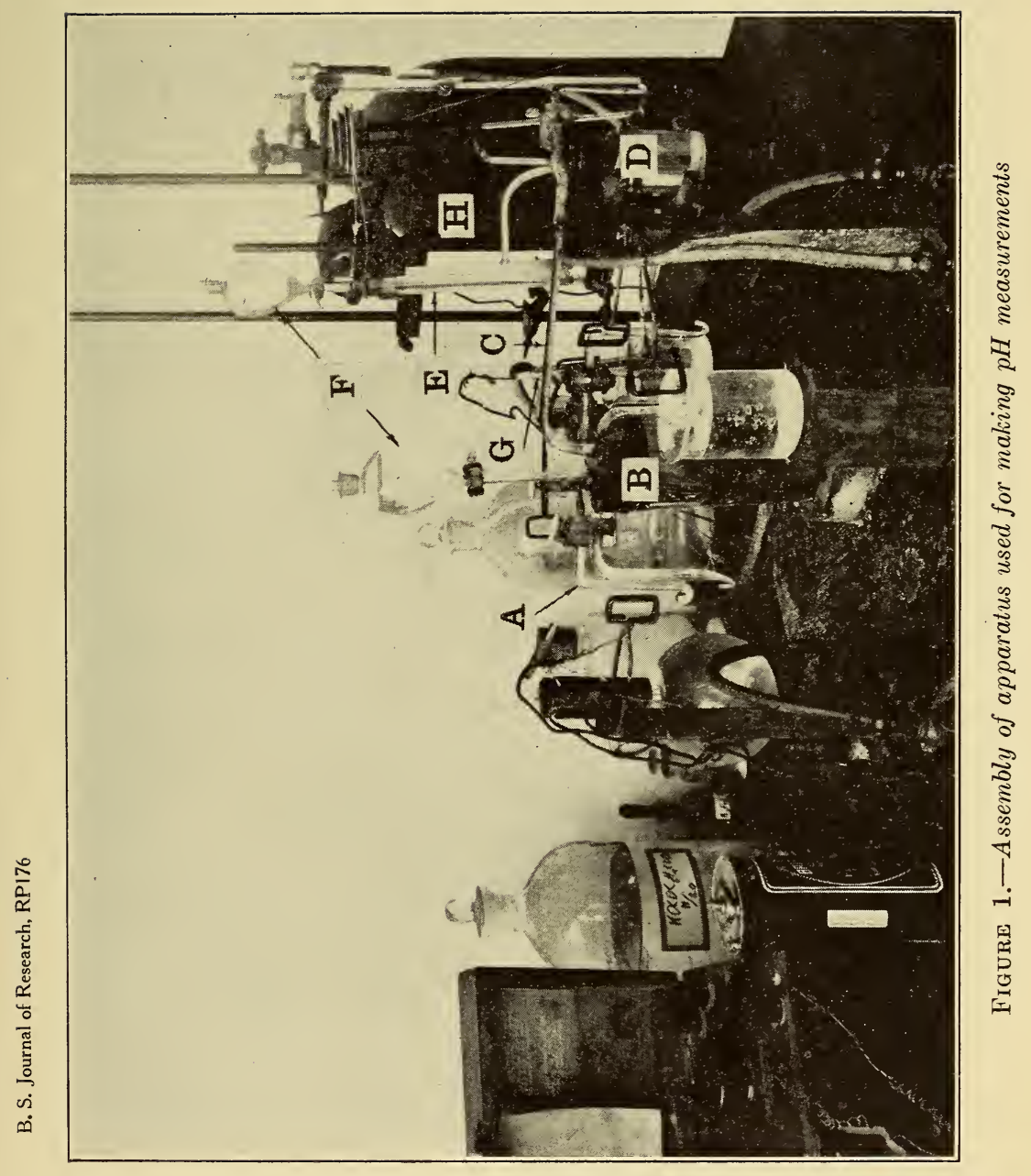


The solutions of tanning materials were made from the commercial solid extracts.

In investigating the $\mathrm{pH}$ values of leather, steer-hide leathers tanned with the following types of tanning materials were used: (1) Powdered chestnut extract, (2) solid ordinary quebracho extract, (3) solid sulphited quebracho extract, and (4) a blend consisting of about 3 parts chestnut extract and 1 part quebracho extract. The first three were tanned at the Bureau of Standards, while the fourth was a commercial leather.

The sulphuric acid was added to the leather samples by immersing them in solutions of concentrations varying from one-half to 8 per cent $\mathrm{H}_{2} \mathrm{SO}_{4}$.

Each sample was analyzed for moisture by the official method of the American Leather Chemists Association, and for total sulphur by oxidizing a sample with nitric acid and then determining total sulphate gravimetrically by the barium sulphate method. The difference between the percentage thus determined and that found in the untreated leather of the same type was calculated as $\mathrm{H}_{2} \mathrm{SO}_{4}$ and taken as the percentage of $\mathrm{H}_{2} \mathrm{SO}_{4}$ in the sample.

\section{EXPERIMENTAL METHOD}

The tanning extracts were taken from stock solutions, the tannin content of which was determined by the official method of the American Leather Chemist's Association.

The $\mathrm{pH}$ values of the leather were measured in accordance with the method of Kohn and Crede. ${ }^{6}$ This consists of weighing $4.9 \mathrm{~g}$ of dry leather into a beaker, adding $100 \mathrm{ml}$ distilled water, and allowing two hours for the system to come to equilibrium before making a reading.

A small quantity $(0.1 \mathrm{~g})$ of $\mathrm{K}_{3} \mathrm{Fe}(\mathrm{CN})_{6}$ was added to the solutions before making the hydrogen electrode measurements to prevent poisoning of the electrodes by copper, which was present in small amounts, being derived, presumably, from the copper linings of extract evaporators. The presence of ferricyanide ion lowered the concentration of copper ion sufficiently to prevent displacement of copper from solution by the hydrogen. No measurable error was found to be introduced by the addition of the $\mathrm{K}_{3} \mathrm{Fe}(\mathrm{CN})_{6}$. The measurements with both electrodes were made on the same solution, an excess of solid quinhydrone being added after the hydrogen e. m. f. was determined. The readings with the quinhydrone electrode were not taken until they became fairly constant.

Check determinations were made on duplicate samples to determine whether the quantity of hydrogen dissolved by the solution in equilibrium with the gas at atmospheric pressure would have a measurable effect on the reading with the saturated quinhydrone electrode. No effect was observed.

The following is an outline giving the nature of the solutions studied:

1. Extract solutions, over a range of tannin concentrations: (a) Chestnut extract, (b) quebracho extract, (c) equal parts chestnut and quebracho extract.

\footnotetext{
6 J. Am. Leather Chem. Assoc., 18 p. 189; 1923.
} 
2. Leather-water equilibrium systems, over a range of weight of leather per $100 \mathrm{ml}$ water: (a) Leather tanned with chestnut extract, containing (1) zero per cent $\mathrm{H}_{2} \mathrm{SO}_{4}$ and (2) $4 \frac{1}{2}$ per cent $\mathrm{H}_{2} \mathrm{SO}_{4}$; (b) leather tanned with sulphited quebracho extract, containing (1) zero per cent $\mathrm{H}_{2} \mathrm{SO}_{4}$, (2) 2 per cent $\mathrm{H}_{2} \mathrm{SO}_{4}$, and (3) 4 per cent $\mathrm{H}_{2} \mathrm{SO}_{4}$.

3. Leather-water equilibrium systems over a range of acid content in the leather: $(a)$ Leather tanned with powdered chestnut extract, (b) leather tanned with solid ordinary quebracho extract, $(c)$ leather tanned with solid sulphited quebracho extract, and $(d)$ leather tanned with commercial blend.

A number of determinations were made on filtered solutions from leather-water equilibrium systems. These solutions gave substantially the same results as when the leather was present, so no further work was done on them.

In order to determine approximately the probable error of a single reading for each of the electrodes, e. $\mathrm{m}$. $\mathrm{f}$. measurements were made for 10 duplicate samples of commercial leather. The probable error of a single observation with the hydrogen electrode was found to be about $0.5 \mathrm{mv}$, and that with the quinhydrone electrode about $1.0 \mathrm{mv}$. Converted into $\mathrm{pH}$, these quantities become 0.008 and 0.017 . In view of the magnitude of these errors the e. m. f. readings were not taken more closely than to the nearest millivolt.

While the work was all done at room temperature and barometric pressure, the calculations are based on a temperature of $25^{\circ}$ and a pressure of $760 \mathrm{~mm}$. The errors introduced by variation in temperature and pressure were neglected, as they were not large in comparison with other experimental errors.

The e. m. f. measurements with the hydrogen and quinhydrone electrodes were calculated to corresponding $\mathrm{pH}$ values, $\mathrm{pH}_{\mathrm{H}}$ and $\mathrm{pH}_{\mathrm{Q}}$, respectively, and these are given as curves showing $\mathrm{pH}$ plotted against the independent variable. (Figs. 2 to 10.) Where the difference between the $\mathrm{pH}$ values given by the two electrodes is plotted as $\mathrm{pH}_{\mathrm{Q}}-\mathrm{pH}_{\mathrm{H}}$, or $\Delta \mathrm{pH}$, the scale for $\Delta \mathrm{pH}$ is on the right-hand side of the graph.

\section{DISCUSSION OF RESULTS}

In none of the systems studied are the results obtained with the hydrogen and quinhydrone electrodes in close agreement. At particular points the two electrodes give the same values, but the results obtained with quinhydrone could not, in general, be substituted without correction for those obtained with hydrogen.

Because of the wide variation in the types of curves showing the quinhydrone correction, no attempt has been made to formulate a general expression for this correction.

No quantitative explanation of the discrepancies observed in any case studied can be offered at present, but several possible causes of errors in the quinhydrone electrode e. m. f. readings may be given.

The ratio of the activities of quinone and quinol in a solution in equilibrium with an excess of solid quinhydrone is changed in the three following ways, (1) by reduction or oxidation of quinhydrone, ${ }^{7}$ (2) by a difference in the effect of dissolved substances on the two

7 G. Hugonin, Cuir. Tech., 13, p. 385; 1924; J. S. L. T. C., 8, pp. 492 and 537; 1924; J. Am. Leather Chem. Assoc., 20, p. 52; 1925 . 


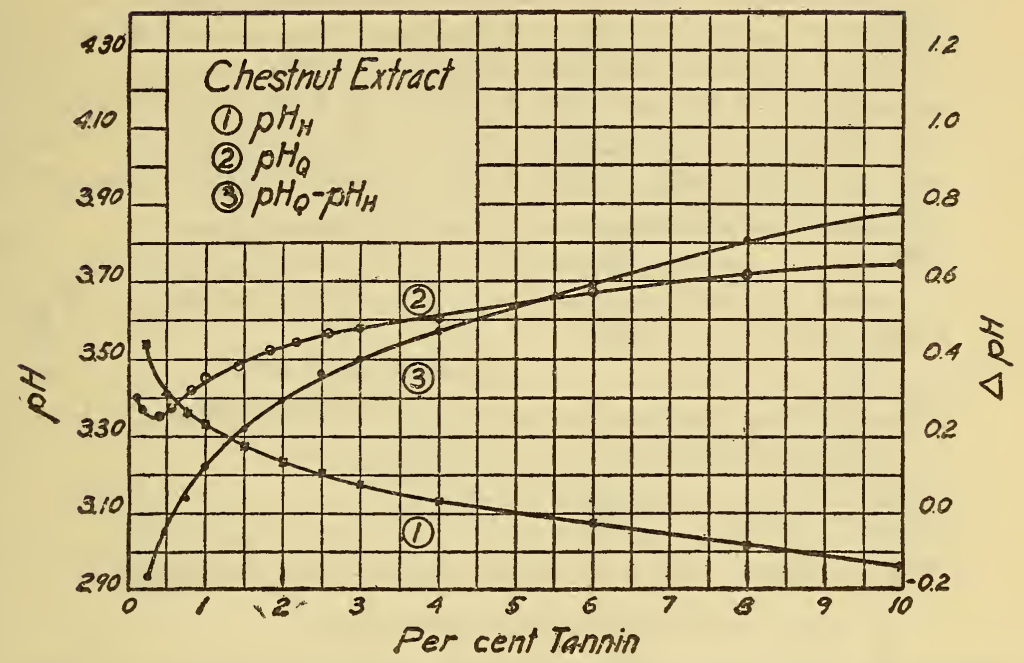

FIGURE 2.-pH measurements in solutions of povdered chestnut wood extract, over a range of tannin concentration

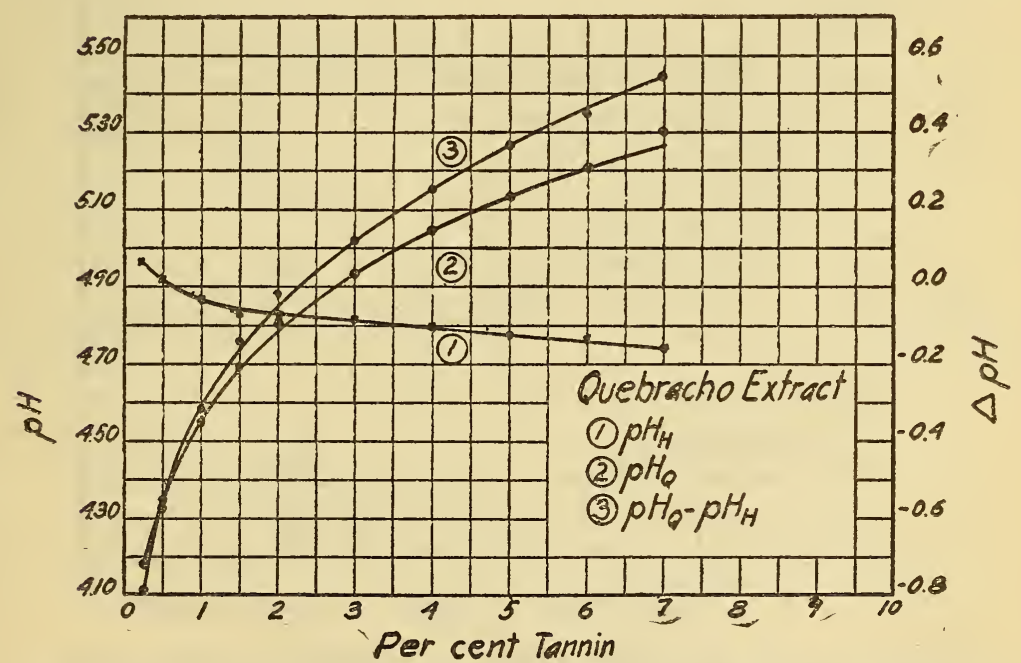

FIGURE 3.-pH measurements in solutions of solid ordinary quebracho axtract, over a range of tannin concentration 


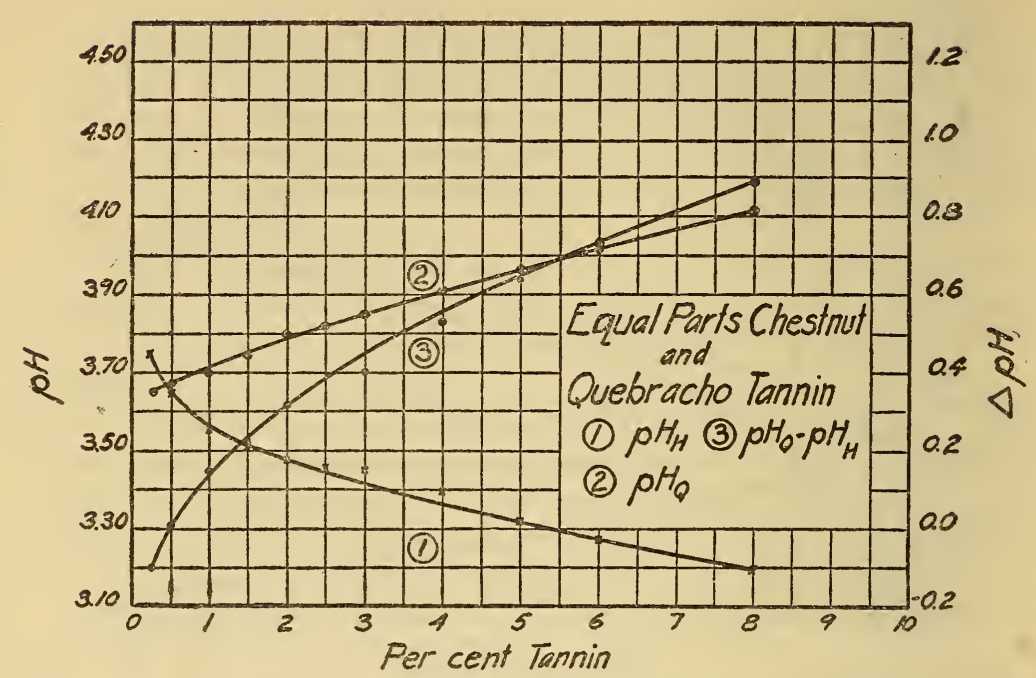

FIgURE 4.- $p H$ measurements in solutions containing equal parts of chestnut and quebracho tannins, over a range of tannin concentration

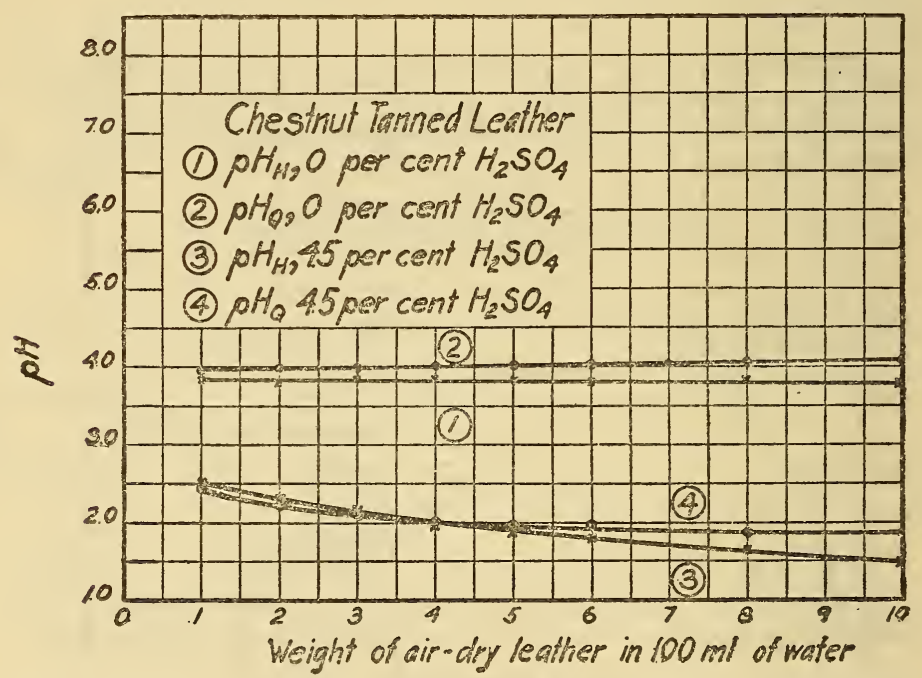

FIGURE 5.-pH measurements in systems consisting of water in equilibrium with leather tanned with chestnut extract, over a range of weight of leather per $100 \mathrm{ml}$ water 


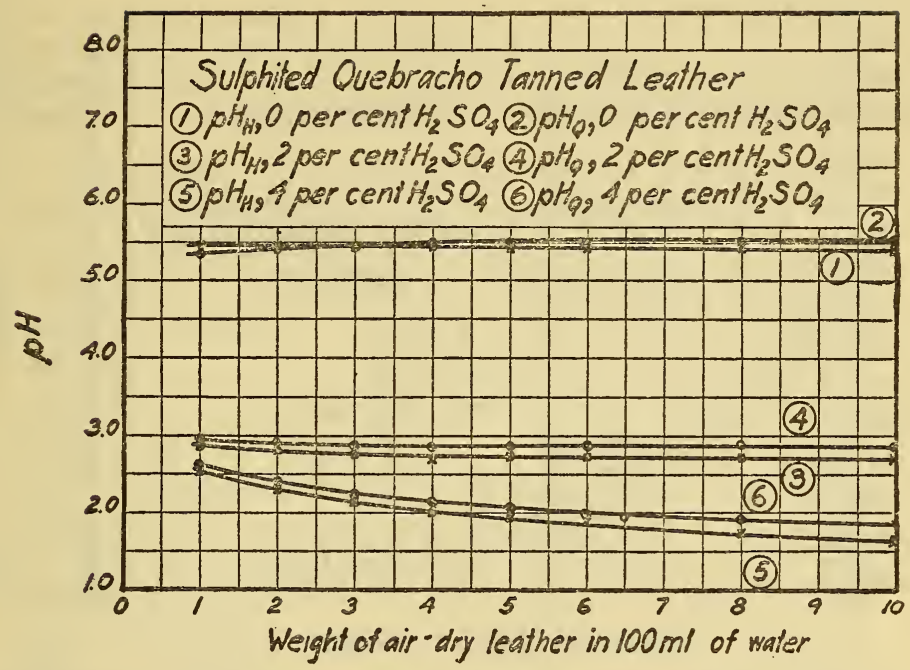

FIGURE 6.-pH measurements in systems consisting of water in equilibrium with leather tanned with sulphited quebracho extract, over a range of weight of leather per $100 \mathrm{ml}$ water

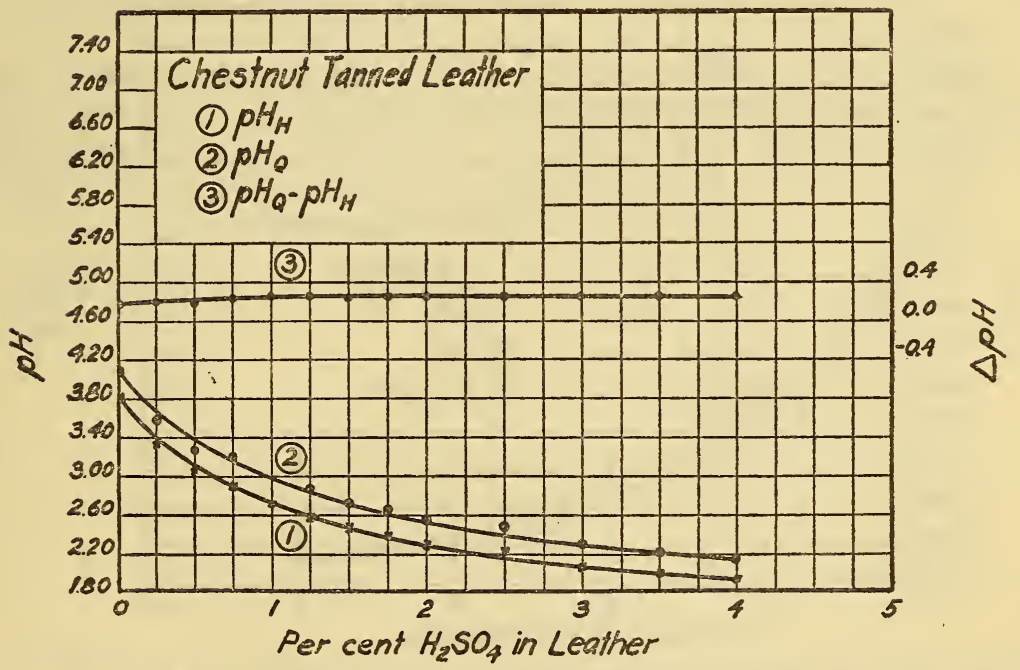

FIGURE 7.- $p H$ measurements in systems consisting of water in equilibrium with leather tanned with chestnut extract, over a range of sulphuric acid content in the leather 


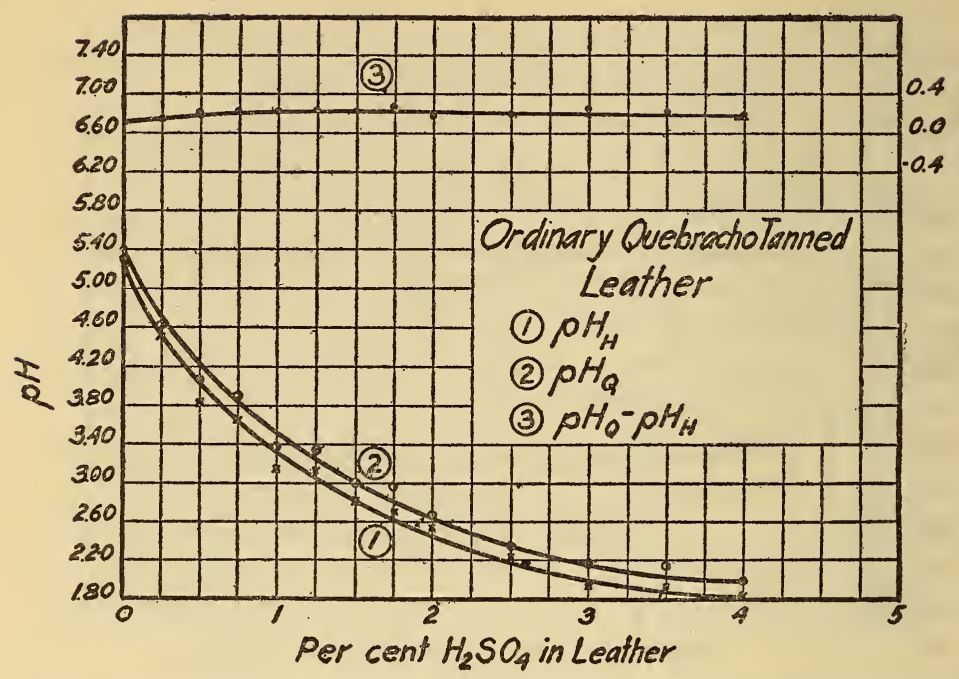

$\frac{1}{2}$

FIGURE 8. $-p H$ measurements in systems consisting of water in equilibrium with leather tanned with ordinary quebracho extract over a range of sulphuric acid content in the leather

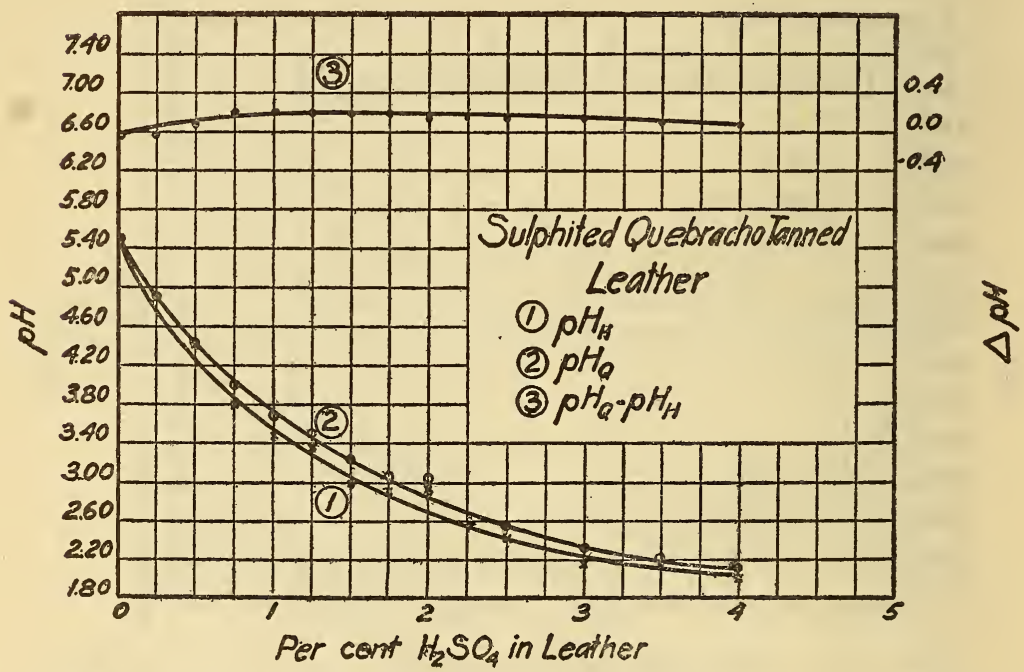

FIGURE 9.-pH measurements in systems consisting of water in equilibrium with leather tannod with sulphited quebracho extract over a range of sulphuric acid content in the leather 
activities, ${ }^{8}$ and (3) by a difference in the quantity of the two compounds adsorbed on the surface of colloidal matter.

In view of the fact that leather and tanning materials contain polyphenolic and other related substances the first effect is probably most important in the cases under consideration.

The experimental results indicate that quinhydrone electrode readings for the $\mathrm{pH}$ of leather water systems can be corrected to corre-

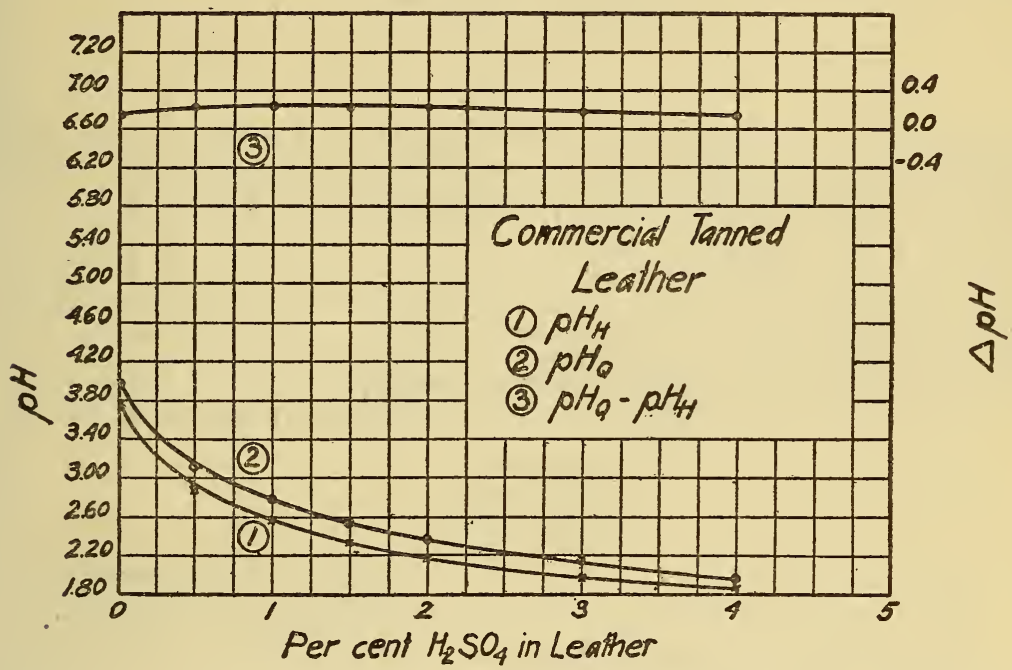

FIGURE 10.- $-p H$ measurements in systems consisting of water in equilibrium with leather tanned with a commercial blend, over a range of sulphuric acid content in the leather

spond with hydrogen electrode readings in case the exact nature of the solutions in question is known. Such corrections have been used successfully in this laboratory. In the case of tanning extracts the errors involved are too great to be disregarded.

Washington, December 19, 1929.

${ }^{8}$ E. Biilmann, Bull. Soc. Chim., 41, p. 213; 1827. 